\title{
Barbariske brøl og blå monotoni
}

\author{
En komparativ karakteristik af Walt \\ Whitmans og Emily Dickinsons vers
}

\section{Mette MOESTRUP}

Jeg er ingen, lyder det hos Emily Dickinson. Jeg fejrer mig selv, lyder det hos Walt Whitman. ${ }^{1}$ To stemmer fra det 19. århundredes Amerika, der på én gang er karakteristiske for det amerikanske og karakteriserede ved at være modsætninger. Dels har Whitman (1819-92) og Dickinson (1830-86) tilnærmelsesvis status som stamfader og stammoder til amerikansk lyrik, dels omtales de som amerikanske arketyper for henholdsvis' 'the public poet' og 'the private poet'. Whitman levede et udadvendt liv i metropolen New York, og Dickinson levede et mere og mere isoleret liv i provinsen Amherst, Massachusetts. Whitman publicerede egenhændigt sin debut Leaves of Grass (1855), han anmeldte den sågar også selv. Dickinson fik kun ganske få digte udgivet - anonymt -i sin levetid. Ifølge Harold Bloom overskygges Whitman og Dickinson ikke af nogen vestlige digtere fra de sidste 150 år. ${ }^{2}$ Hvorom alting er, hører disse to stemmer ikke blot hjemme i amerikansk kanon.

I følgende komparative karakteristik af Whitmans og Dickinsons vers, søges røst og rytme indkredset med verselinien som dén enhed, inden for hvilken læsningerne primært finder sted. At verset således er akse, beror dels på den antagelse, at verselinien som sådan er et væsentlig lyrisk genretræk, dels på den formodning, at Whitman og Dickinson på hver deres måde rokker ved versets traditionelle integritet; Whitman igangsatte det 
amerikanske free verse, og Dickinsons egenartede rytme opstod $i$ et spændingsforhold til engelsk common meter. I løbet af læsningerne vil metrik- og rytmeteori blive aktiveret i forhold til det lyriske materiale; netop det at integrere de metriske og rytmiske aspekter i det analytiske arbejde - f.eks. medtænke rytmisk-retoriske figurer - er en metodisk udfordring.

\section{Om Dickinsons værk}

Efter Emily Dickinsons død fandt hendes søster, Lavinia, et overvældende antal digte. Materielt set bestod værket af en kolossal ophobning af håndskrevne ark, der var samlet i pakker, bundet sammen med sejlgarn. Ganske vist var Dickinsons familie og venskabskreds bekendt med, at hun skrev digte, men ingen havde troet, at livsværket var så omfangsrigt - i alt 1775 digte. I 1890 udkom Poems of Emily Dickinson, et udvalg på 115 digte. Her stod kritikeren T. W. Higginson for visse 'korrektioner' af rim, rytme og metaforik, som i nogen grad udviskede digtenes særegenhed. Til samme Higginson sendte Dickinson et brev d. 15. april 1862, hvori hun bad ham tage stilling til, om hendes digte åndede, og Higginson er først og fremmest kendt for, at han frarådede hende publikation. Blandt andet fandt han hendes lyriske gangart spasmodisk. I et brev, hvis gangart for øvrigt minder meget om digtenes, responderede Dickinson, at tanken om udgivelse lå hende lige så fjernt som firmament for fiskefinner. ${ }^{3}$ I takt med at Dickinsons lyrik vandt anerkendelse, blev flere og flere af 'fejlene' udgivet i deres oprindelige version. Dog var det ikke før 1955, at en gennemarbejdet og troværdig udgave af Dickinsons samlede værk udkom, redigeret af Thomas $H$. Johnson. Altså en forsinkelse på et århundrede - Dickinson begyndte at skrive digte i 1850'erne.

De bundtede pakker af digte bar spor af en kronologisk orden, men ikke antydningen af en storform. Dickinsons værk bærer i usædvanlig høj grad præg af at være posthumt, og det er et vilkår for læsningen, at hendes vers allerede $i$ oversættelsen fra håndskrift til typografi er blevet udsat for tydning og tolkning. 


\section{Tre anslag}

Tre af Dickinsons mest berømte digte er nr. 280, 465 og 937, der dateres til cirka 1861, 1862 og 1864. At der er grund til at sammenholde netop disse tre digte, antyder allerede deres anslag. Alle tre åbningslinier flår et paradoksalt rum op. Desperation og køligt tilbageblik kolliderer, in medias res, i jeg-figurens røst. Stemmeføringen klinger på én gang harmonisk og dissonant, hvilket øjeblikkeligt afsætter en skærende diskrepans.

I felt a Funeral, in my Brain, (280)

I heard a Fly buzz - when I died - (465)

I felt a Cleaving in my Mind - (937)

Ikke blot er „I" det første ord i samtlige anslag; åbningsliniernes syntaktiske struktur er i det hele taget slående ensartet - og særdeles enkel. Sætningerne falder i to dele, hvoraf den første fremsætter jeg' ets registrering i datid, og den anden placerer denne i tid og rum. Endog er såvel ordstilling som ordlyd næsten identisk i nr. 280 og 937, bortset fra „Funeral" overfor „Cleaving" og „Brain" overfor „Mind". Hvor begge disse liniers verbum er emotionelt, "I felt", er der i nr. 465 tale om perception, "I heard", og hvor følelsen placereres i rum, ,in my Brain/Mind", placeres hørelsen i tid, "when I died". Desuden virker nr. 465's iøjne-. springende flue umiddelbart mere konkret end begravelse og spalten. Dog er det ikke fluen som sådan, men dens svirren eller summen, der tiltrækker jeg'ets døende hørelse, hvormed objektet ikke er så håndgribeligt endda. Danner nr. 280 og 937 et syntaktisk par, synes den eksplicitte pegen på død som motiv til gengæld at sammenkæde nr. 280 og 465 tematisk, idet „Cleaving in my Mind" snarere vækker associationer til sindslidelse end død. Paradokset har muligvis den mest chokerende effekt i dé to linier, hvor begravelse og døen iscenesættes i datid, men de tre anslag er fælles om at udspænde det lyriske jeg mellem følelse og følelsesløshed, mellem kaos og kontrol. „I felt a Funeral, in my Brain,", ,I heard a Fly buzz - when I died -" og ",I felt a Cleaving 
in my Mind" tager alle afsæt i talefiguren som et paradoksalt udgangspunkt og åbner for lakuner af kompleksitet gennem en simpel syntaktisk struktur. Endvidere slår åbningslinierne samme metrum an.

Digtene er komponeret $i$ henholdvis 5, 4 og 2 strofer, men fælles for dem er, at stroferne består af fire linier. Kvartetterne er, for alle tre digtes vedkommende, skrevet i common meter, også kaldet 'fourteeners'. Det vil sige, at hver kvartet består af to kupletter med syv betoninger, fordelt på første linies otte og anden linies seks stavelser. Samtlige kvartetter følger med næsten usvigelig regelmæssighed dette 8-6-8-6 liniemønster og den jambiske alternation. En regularitet og orden, der står i kontrast til digtenes motiver. For alle tre digte gør det sig ydermere gældende, at lyd og rytme spiller en bemærkelsesværdigt fremtrædende rolle.

\section{Drum \& Bell}

I "I felt a Funeral, in my Brain", træder lyden ind som en trampen allerede i første kvartet. Følelsen, der i åbningslinien lokaliseres $i$ hjernens indre rum, som en slags hallucination, konkretiseres nu i et ydre scenario med sørgende aktører, der tramper og tramper.

I felt a Funeral, in my Brain, And Mourners to and fro

Kept treading - treading - till it seemed

That Sense was breaking through -

Den ordrette gentagelse "treading - treading -" betoner en monotoni i de sørgendes skridt, der giver ekko i anden strofes ceremoni eller gudstjeneste, som sammenlignes med „a Drum”.

And when they all were seated,

A Service, like a Drum -

Kept beating - beating - till I thought

My Mind was going numb - 
Kvartetternes tredie linier har en ensartet sætningsstruktur, hvormed de rimer på tværs af de strofiske rammer. De gentagende og genlydende vers "Kept treading - treading - till it seemed" og "Kept beating - beating - till I thought" har desuden et onomatopoietisk præg. Hermed accentueres hallucinationens transformation til lydlig vision. Med trommen som simile slår disse to strofer fast, at det er lydlige slag, der bevirker "That Sense was breaking through -" og at "My Mind was going numb-". Her skal indføjes, at "breaking through" rummer en tvetydighed mellem gennembrud og sammenbrud. Endskønt det indre rum er iscenesat $i$ en ydre situation, bibeholdes en toven $i$,"it seemed" og "I thought". Hvor "breaking through" både har positive og negative konnotationer, er "numb", der betyder stivnet eller død, entydigt negativt. Og denne rigos mortis rimer på "Drum”. Trommen afgiver således betydning udover det semantiske og metaforiske, nemlig i kraft af det metronomiske " -beating - beating -" og det rimende sammenfald med "numb".

Det er langt fra alle digtets vers, der har enderim, hvorfor rimmønstret kan forekomme vilkårligt. Dog skifter stroferne mellem halve og fulde krydsrim (abcb), som det høres i de ovenfor citerede kvartetter, hvor første strofes enderim "fro-through" er halvt eller urent, mens anden kvartets "numb-Drum" har fuld samklang. Dette mønster fortsættes i tredie (,,Soul - toll", halvrim) og fjerde („Ear - here", fuldrim) strofe, men afbrydes i femte kvartet, hvor krydsrimet kun antydes gennem afslutningskonsonanten (,down - then"). At rimmønstret således følger digtets struktur, snarere end at lægge sig efter et konventionelt skema, er formodentlig én af de måder, hvorpå „I felt a Funeral” yder den ellers yderst traditionelle form modstand. Udover enderim, gives der en række lydrim i digtet, der for størstedelen har lydmalende effekt, som f.eks. i tredie strofes knirkende "creak across". Her indlejres det lydlige endvidere i verbet ",heard".

And then I heard them lift a Box

And creak across my Soul

With those same Boots of Lead, again,

Then Space - began to toll, 
I første strofe tramper de sørgende frem og tilbage, $i$ anden strofe har de sat sig ned, og trommen slår og slår. Her i tredie strofe løfter de "a Box", der i konteksten må udlægges som en kiste, hvorefter de fortsætter deres gang med støvler af bly eller forspring („Lead" er semantisk tvetydigt). Gentagelsen emfaseres gennem "same" og "again". Som en art rim i venstre margen, understreger "And", "And" denne fortsættende repetition. "And" optræder én gang i både første og anden strofe, to gange i tredie og fjerde strofe, for så at være begyndelsesord i hver eneste af femte strofes vers. Endnu et eksempel på, at digtets rim krydser strofiske grænser er, at "toll", der betyder en langsom ringen, som ved dødsfald, kædes sammen med fjerde strofes „Bell”. Digtet bevæger sig nu fra trommens monotone slag til et ringende rum, en kimende klokke. Trommen og klokken kan siges at være retoriske markører for dén metrisk-rytmiske og lydlige signifikans, som digtet signalerer.

As all the Heavens were a Bell, And Being, but an Ear,

And I, and Silence, some strange Race

Wrecked, solitary, here -

And then a Plank in Reason, broke, And I dropped down, and down And hit a World, at every plunge, And finished knowing - then -

Altså: rummet begyndte at ringe, som om alle himlene var en klokke og væren ikke andet end et øre. Overfor denne samhørighed mellem den himmelske klokkes lyd og det værende øres lydhørhed, står jeg'et og stilheden alene, forliste „here-". Her synes således at være det bristepunkt, hvorfra et fald tager fart med endnu en gentagelses-figur, „down, and down-". Sålænge jeg'et i det mindste har vaklet mellem følelse og følelsesløshed, har hørelsen været katalysator for en omend forviredet, obscur forbindelse til scenariet med de sørgende. Men dén stille isolation, som tager form i fjerde strofe, fører et fald med sig, der udelukker såvel det indre som det ydre rum i en opløsning. De to sidste stro- 
fer modstiller implicit himmel overfor helvede, opadstigen overfor fald, hvormed digtets afslutning trækker energi fra denne modsatrettede bevægelse. Tempoet stiger i takt med faldet, idet gentagelsen And, And, And, And påpeger, at strofen er i et narrativt tidspres. I de sidste linier spiller "finished" sammen med "-then-", som både kan understøtte og undergrave finaliteten. Tankestregene omkring ", -then-" må siges at være flertydige. Er de pauser, der omkranser en udånding? Forudgriber og understreger de stilhedens uudsigelighed og digtets bogstavelige ophør? Eller angiver de, at faldet ikke standser, men fortsætter ud over digtets ramme? Der er i alt 18 kommaer og 12 tankestreger i digtet, men ikke et eneste punktum. Selvom digtet konstant kredser om ophør, konkretiseret i begravelsen, udebliver en egentlig kadence. Endog kan digtets sidste linie læses som en art evighedsmaskine, idet sidste linie fører tilbage til første linie: 'And Finished knowing - then -/ / I felt a Funeral in, my Brain'. Man kan sige, digtet iscenesætter et gradvist ophør, som en slags skindød, hvis død træder i kraft i løbet af begravelsen som en selvopfyldende profeti. Men samtidig cirkler digtet om en tidslig forskydning mellem finalitet og fortsættelse, og det er ikke mindst denne dobbelte narrative struktur, der levendegør døden i digtet.

\section{Blue Buzz}

Den uforudsigelige rimstruktur er som sagt én af de måder, hvorpå den konventionelle strofiske form gives egenart hos Dickinson. Tankestregen er en anden. Dickinson anvender tankestregen utraditionelt både i grammatisk og retorisk henseende. Hvor de skæve rim rokker ved lydens renhed (halve rim kaldes også urene rim), støder tankestregen til det regelmæssige metrum. I "I heard a Fly buzz - when I died -" klinger enderimene kun ét sted sammen, nemlig i slutstrofen „me - see”; resten er forskudte, nærmest rester af rim. Tankestregen er eneste tegnsætning, til gengæld er der 19 af disse mærkværdige "dashes".

Så sent som i 1950'erne var flere udgivere af dén opfattelse, at Dickinsons anvendelse af tankestreger var ubetydelig og sågar 
forstyrrende. Et eksempel er John Crowe Ransoms redigering af "I heard a Fly Buzz - when I died -" fra 1956," hvori samtlige tankestreger er fjernet og delvist erstattet af almindelig tegnsætning. ${ }^{5}$ Hvor gennemgribende de små ændringer er, fremgår tydeligt, når man sidestiller de to versioner. Her ses sidste strofe, øverst i T. H. Johnsons kanoniserede udgave, nederst i John Crowe Ransoms fortolkning.

With Blue - uncertain - stumbling Buzz Between the light - and me And then the Windows failed - and then I could not see to see -

With blue, uncertain, stumbling buzz Between the light and me; And then the windows failed, and then I could not see to see.

Hvis man læser de to strofer højt, kan man høre, hvor forskellig recitationen lyder - selv om ordene er de samme. I Ransoms udgave faldèr ordene ganske gnidningsløst sammen med den jambiske alternation. I Johnsons version, der lægger sig så tæt op ad Dickinsons manuskript som muligt, støder recitationen på friktion samt en fragmenteret karakter. Tankestregen giver metret modrytme og bryder verset op i mindre enheder. Der er en spænding mellem brudstykke og sammenhæng, der er en tøven eller forpustet vejrtrækning bag slagene (dette mærkes markant, hvis man trækker vejret ved hver tankestreg). Intonationen er usikker, som krakelerende is.

Ransoms tendens til at intonere grammatisk korrekt ses endvidere deri, at han lukker strofens åbenhed med et punktum. Af det originale, håndskrevne "I heard a Fly buzz - when I died -" fremgår det, at manuskripterne er iboende et problem blandt andet vedrørende tankestregerne. Dickinsons tankestreger er tit små irregulære streger, der ikke modsvares præcist af de eksisterende typografiske tegn. I princippet er de derfor umulige at gengive i komplet overensstemmelse med originalen. Sine steder er det endog svært at sondre mellem punktummer og tankestreger, 
hvilket til en vis grad kan være et argument for, at sondringen ikke har afgørende betydning, og således understøtte Ransoms redigering. Imidlertid er det afsluttende tegn i manuskriptet "I heard a Fly buzz - when I died -" afgjort en tankestreg og ikke et punktum. Og såvel formmæssigt som tematisk gør det en forskel for fortolkningen, idet tankestregen for det første signalerer en manglende eller svævende kadence snarere end afrunding, og for det andet peger på døden som en gradvis sløring snarere end et brat, definitivt mørke. 6

I "I felt a Funeral, in my Brain," spiller en lydlig vision sammen med stilhed. I "I heard a Fly buzz - when I died - " føjes en synsmetaforik til samspillet.

I heard a Fly buzz - when I died The Stillness in the Room Was like the Stillness in the Air Between the Heaves of Storm -

The Eyes around - had wrung them dry And Breaths were gathering firm For that last Onset - when the King

Be witnessed - in the Room -

I willed my Keepsakes - Signed away

What portion of me be

Assignable - and then it was

There interposed a Fly -

With Blue - uncertain stumbling Buzz -

Between the light - and me -

And then the Windows failed - and then -

I could not see to see -

Tilsvarende „I felt a Funeral - in my Brain -" muliggør dette digts afslutning en tilbagevending til begyndelseslinien: 'I could not see to see - / / I heard a Fly buzz - when I died'. I tilgift til det cykliske potentiale, har også dette digt en successiv struktur, idet afslutningsstrofen krystalliserer ophørsmomentet. Imidlertid er denne gradvise sløring present konstant $\mathrm{i}$ kraft af tilbageblikkets 
paradoksale udgangspunkt. I digt nr. 465 finder et tilbageblik i tilbageblikket desuden sted, idet fluens summen, der åbner digtet, siden placeres i en krọnologi i tredie og fjerde strofe: „- and then it was".

Digtets åbnings- og afslutningsstrofe markerer dét perceptionelle dobbeltfelt, digtet opererer med; et spændingsfelt mellem "I heard" og „I could not see to see”. Agniezska Salska læser digtet som en tematisering af ,livets ebben ud (..) gengivet i form af sansernes tiltagende svækkelse” og anfører videre, at „hendes vision bliver smallere og smallere, indtil øjnene udelukkende fikserer på fluen", hvorefter den sidste kuplet citeres.7 At se fluen som noget, jeg'et slet og ret ser, må simpelthen siges at være en fejllæsning. De første ord er jo „I heard a Fly buzz,. Og „Buzz” er stavet med stort i fjerde strofe. Betoningen af denne summen kan dog næppe heller udlægges således, at fluen er en entydigt lydlig figur. I samspil med strukturens på én gang cykliske og successive svingning mellem det auditive og optiske, figurerer fluen snarere både i lyd og billede. I første strofe står fluens summen i kontrast til den "Stillness", der fordobles og forstørres gennem gentagelse og natursimilens 'stilhed før storm'. Men „buzz" kan både betyde summen og svirren, altså både være et minimum af lyd og bevægelse i dette rum af fortættet stilhed. En svirrende prik på nethinden og en dirren i trommehinden. Dickinsons tvetydiggørelse af fluen ses og høres tydeligst i liniebrydningen mellem tredie og fjerde strofe, hvor "Fly" først står alene, og derefter forbindes med „Blue - uncertain stumbling Buzz", som gennem farven både peger på fluens kulør og tonen i dens summen. Hvis man er opmærksom på, at fluen næppe opdukker to gange, men at dens opdukken snarere gentages, kan man opfatte 'Blue Buzz' som dén lydlige og visuelle figur, der generer digtets tidsligt forskudte struktur.

\section{Sound}

I „I felt a Cleaving in my Mind-" spiller lyd sammen med, eller rettere mod orden. Digtet, der er det korteste af de tre digte, tematiserer et forgæves forsøg på at skabe sammenhæng. Ligesom 
i digt nr. 280 konkretiseres følelsen, idet jeg'et prøver at hele sin indre splittethed ved at sy hjernen sammen.

I felt a Cleaving in my Mind -

As if my Brain had split -

I tried to match it - Seam by Seam -

But could not make them fit.

The thought behind, I strove to join

Unto the thought before -

But Sequence ravelled out of Sound

Like Balls - upon a Floor.

Tankernes kronologi eller orden vikler sig ud af lyd som garnnøgler langs et gulv, hedder det i dette digt, hvor "split" rimer på "fit" og punktummer afgrænser strofer. Hvad vil billedet sige? Peger garnnøglerne tilbage på "Seam by Seam", som dén tråd, hvormed jeg'et forsøger at lappe kløften i hjernen? Billedet „Like Balls - upon a Floor." vækker visuelle associationer til et virvar af tråde i retningsløs bevægelse. Ikke en tekstur, hvor trådene er vævet sammen. Ikke en kryptisk labyrint, hvorigennem én tråd viser vej. Ikke en Ariadne-tråd, men et kaotisk sammensurium af tråde. Hvis dette er et billede på hjernen, i hvis tanker, der hverken er orden i sted (,behind") eller tid (,before"), hvor kommer "Sound" så ind i billedet? Det er lydløst, når garnnøgler ruller ud på et gulv. Men det er som om, ordet "Sound" bliver stående, som dét, billedet filtrer sig ud af og falder ned fra. Med andre ord har "Sound" en nærmest emblematisk karakter i digtet. Det samme gør sig gældende i nedenstående strofe, 8 hvor lyd affirmeres som noget, der transcenderer verdens konklusion.

This World is not Conclusion.

A Species stands beyond -

Invisible as Music -

But Positive, as Sound -

At rækkefølgen vikler sig ud af lyd i det sidste af disse tre digte, der tager afsæt $i$ et ensartet anslag, peger endvidere i retning af, 
at digtene processuelt eksperimenterer med variationer indenfor en traditionel formmæssig ramme. Iboende dette eksperiment er en refleksion over metrum, rytme og lydlighed, der markeres gennem figurerne Drum, Bell, Blue Buzz og Sound.

\section{Om Whitmans værk}

På titelbladet i Leaves of Grass, der udkom i 1855, står der intet forfatternavn. Et portræt synes at stå i stedet for navnet - der imidlertid dukker op to steder blandt bogens blade. På copyright-siden forefindes døbenavnet Walter Whitman, og i åbningsdigtet, som siden har fået titlen "Song of Myself", lyder det som følger: "Walt Whitman, an American, one of the roughs, a cosmos". Udeladelsen af en enkelt stavelse etablerer en talefigur, der hverken er en anden eller den samme som personen Walter Whitman, hvormed ændringen kan siges at være en katalysator for forbindelsen mellem det individuelle og det universelle; således kan Walt Whitman være et kosmos.

Mens Dickinsons værk som sagt i allerhøjeste grad var efterladt til udeforståendes redigering, stod Whitman selv for en redigeringsproces, der i løbet af hans forfatterskab ændrede Leaves of Grass gennemgribende på mange niveauer. Gennem 36 år vedblev Whitman at arbejde med værket, der blev udgivet i ni forskellige udgaver i hans livstid. Den finale udgave, også kaldet "Deathbed" udgaven, fra 1891-92,9 adskiller sig såvel strukturelt som kvanitativt fra den første udgave af Leaves of Grass fra 1855, der består af 12 digte mod den finale udgaves 383 digte. Spørgsmålet om, hvilken af udgaverne, der bør kanoniseres, er uundgåeligt. Hvor det posthume er et vilkår for Dickinsons værk, er Whitmans værk uadskilleligt fra det processuelle.

\section{Anslag - det originale versus det finale}

Digtet, der åbner Leaves of Grass, 1855, er uden titel. I løbet af Whitmans processuelle omskrivning, nærmere bestemt i 1881, fik digtet dén titel, hvorunder det er kanoniseret - "Song of Myself". I „Deathbed"- udgaven er „Song of Myself" ikke længere 
åbningsdigt, men det sidste digt i en gruppering, der hedder „Inscriptions". Ligesom det udvidede værk er blevet struktureret i grupper, er digtets dele blevet nummereret. Allerede i anslaget finder en ændring sted: „I celebrate myself" bliver til „I celebrate myself, and sing myself". I den sidste udgave figurerer sang som substantiv i titlen, "Song of Myself", og som verbum i anslaget, hvor jeg'et ikke blot fejrer, men også synger eller besynger sig selv. En lille tilføjelse, som ikke desto mindre antyder en fremhævelse af det orale. Mellem de to versioner spores nogle gange en bevægelse fra det auditive til det orale, fra lytten til syngen. I den originale version fremstår jeg'et som et åbent, passivt øre:

I think I will do nothing for a long time but listen, And accrue what I hear into myself.....and let sounds contribute toward me.

Det auditive er ikke bortfaldet i den finale udgave, men sangen er indskrevet. Lydene bidrager ikke længere "toward me”, men "toward it". Jeg'et, der før var et lyttende medium, er nu snarere sanger eller komponist:

Now I will do nothing but listen,

To accrue what I hear into this song, to let sounds contribute toward it.

I sin introduktion til 1855-udgaven skriver Malcolm Cowley, at titlen "Song of Myself" er digtets "oprindelige intention fuldstændig utro", blandt andet med henvisning til ovenstående forskydning. Cowley kritiserer den aktive bevidsthed, hvormed jeg'et i den finale version lytter til lyde med henblik på at forvandle "sound" til "song". Denne selvreferentialitet er nemlig i uoverenstemmelse med dét, som Cowley kalder "an ecstasy of hearing", den blotte, lystfyldte lytten i 1855-udgaven. Heraf kunne man udlede, at 1855-udgaven ingenlunde har med sang at . skaffe. Imidlertid forefindes ordlyden „song of me" i såvel 1855som "Deathbed"-versionen. 
The feeling of health....the full-noon trill....the song of me rising from bed and meeting the sun.

The feeling of health, the full-noon trill, the song of me rising from bed and meeting the sun.

Citaterne eksemplificerer nogle karakteristika for Whitmans redigering. Dels er aposiopeser (....) erstattet af kommaer, dels er liniebrydningerne, forskellige. Til trods for ændringerne, som ikke skal forklejnes, er det bemærkelsesværdigt, at sangen er eksplicit i begge citater. Endog træder "song of me" tydeligere frem såvel grafisk som rytmisk i det første citat. Omend sangen udhæves i den finale versions titel og anslag, implicerer den originale måske en udspændthed mellem det auditive og det orale. I dét perspektiv kan titlen "Song of Myself" antageligt høres som en selvfortolkning snarere end en selvforfalskning. Når jeg anvender titlen "Song of Myself" i forbindelse med 1855-udgavens titelløse åbningsdigt, er det ud fra dén formodning, at processen udmundede $i$ en retrospektiv genre-betegnelse snarere end et falsk varemærke. At det lyttende og syngende spiller sammen $i$ dette kolossale, rapsodiske digt.

\section{Cyklisk rapsodi \& „uniform hieroglyphic “}

Med rapsodisk menes, snarere en fragmentarisk, en sammensat mangfoldighed. På den ene side rummer digtet et virvar af varietet, af dele og detaljer - ",any thing is but a part", som det lyder et sted. På den anden side afspejler hver del en helhed - „I hear and behold God in every object", som det lyder andetsteds. Her skal det bemærkes, at det guddommelige ingenlunde begrænser sig til Gud i kristen forstand, men nærmere er et princip, der involverer jeg'ets allestedsnærværelse. Myriader af motiver, scenarier og narrationer indoptages i digter-jeg' et, dette omni-ego, der gør det modsætningsfyldte til mangfoldighed. Som i denne berømte strofe:

Do I contradict myself?

Very well then....I contradict myself;

I am large....I contain multitudes. 
En rapsode, kunne man kalde dette jeg. En rapsode er en omvandrende sanger, der foredrager episke digte. Denne rapsode synes dog at indlejre det omvandrende i det fortællende -,I take part...I see and hear the whole" - og det episke glider, støder, hvirvler sammen med det cykliske. Denne rapsode ophøjes og ophæves som en instans, der transfigurerer stemmer - "Voices (..) by me clarified and transfigured". Det volumniøse digt, hvis afsnit i "Deathbed"-udgaven er nummereret fra 1 til 52, udfolder sig næppe kronologisk. Umiddelbart synes digtet at samle et væld af digressioner i vækst. Stumper og stykker af fortællinger kædes sammen hulter til bulter, og alligevel er det sammenkædningerne, snarere end det kaotiske, der er overvældende. En rapsodi kan også betyde et musikstykke, der er sammensat af forskellige melodier. "Song of Myself" kan beskrives som en montage af melodier , ,....... word en masse", der varierer i volumen og klangfarve, fra forførende hvisken til profetiske skrig.

Den sammensatte mangfoldighed omkranses af hvirvlen. Såvel i digtets begyndelse som afslutning, kredses der om malstrømme. Jeg'ets opdukken og forsvinden spiller øjensynligt sammen med disse "eddies". På første side figurerer "the eddies of the wind" $\mathrm{i}$ forbindelse med jeg'ets åndedræt og hjerteslag. Denne forbindelse kommer jeg nærmere ind på i afsnittet , Respiration \& inspiration"; foreløbig skal det blot anføres, at ordene åbner sig for eller slippes løs i denne hvirvlen:

The sound of the belched words of my voice.....words loosed to the eddies of the wind,

På sidste side genfinder man „eddies" dér, hvor jeg'et opløser sig selv:

I depart as air....I shake my white locks at the runaway sun, I effuse my flesh in the eddies and drift it in lacy jags.

At jeg'et strømmer ud ("effuse") i og med malstrømmene, gør ikke nødvendigvis "eddies" til en negativ drivkraft. Tværtom 
virker turbulensen som en frisat force, en stærk energi. Rapsodien er som sagt hverken blot fragmentarisk eller episk. Det er en cyklisk rapsodi, den hvirvler omkring sig selv. Igen og igen.

Gentagelser, ekkoer, parallelismer falder i øjne og øre i dette digt, i dets verselinier, i dets strofer, $i$ afsnittene. Det minimale genlyder i det kolossale; mangfoldighedens forskellighed kædes ikke mindst sammen gennem repetition og redundans. Gennem niveauernes udskiftelighed. I sjette afsnit peger et barns spørgsmål på titlen Leaves of Grass, og i digterens spørgende svar gentages „Or I guess". I șamme sekvens figurerer "a uniform hieroglyphic".

A child said, What is the grass? fetching it to me with full hands; How would I answer the child?....I do not know what it is any more than he.

I guess it must be the flag of my disposition, out of hopeful green stuff woven.

Or I guess it is the handkerchief of the Lord, A scented gift and remembrancer designedly dropped, Bearing the owner's name someway in the corners, that we may see and remark, and say Whose?

Or I guess the grass is itself a child....the produced babe of the vegetation.

Or I guess it is a uniform hieroglyphic, And it means, Sprouting alike in broad zones and narrow zones,

Græsset er flertydigt; det er et flag i håbets farve, en tekstur, der forvandles til Guds lommetørklæde, noget grønt, der omdanner sig til et barn af plantevækst, en kim, der bliver til en ensartet hieroglyf, der betyder Spirende ens i brede zoner og smalle zoner. Græsset er mere end flertydigt; det er et spørgsmål, der stiller sig selv. Det er i barnets hænder og dog uhåndgribeligt; ubegribeligt enkelt. Monstro den ensartede hieroglyf kan ses som emblematisk for den cykliske rapsodi? Giver den genklang i digtets utal af ekkoer? 


\section{Respiration \& inspiration}

Vindens malstrømme, "the eddies of the wind", hvirvler som sagt i forbindelse med åndedræt og hjerteslag i andet afsnit. Luften drages ind i digtet gennem en gradvis perceptionel renselse. Først trækker jeg'et vejret i huse og rum fulde af parfumer, men modstår den duftende beruselse. Herefter træder jeg'et ud af de duftende rum for at gå den duftløse, rene atmosfære i møde med vidtåbne sanser og utilsløret nøgenhed. Med suggererende sanselighed lades dette forspil erotisk. Forelsket, begærlig bevæger jeg'et sig hen mod en bred:

The atmosphere is not a perfume....it has no taste of the distillation....it is ordorless,

It is in my mouth forever....I am in love with it, I will go to the bank by the wood and become undisguised and naked, I am mad for it to be in contact with me.

I efterfølgende strofe står jeg'et måske ved ,the bank by the wood". Træer og hav figurerer $i$,The sniff of green leaves and dry leaves, and of the shore and/ darkcolored sea-rocks". Men ligesom allusionen til titlen Leaves of Grass blander årstider sammen i grønne og visne blade, udvides scenariet gennem sansninger af alt fra elskovsrod til hø $i$ laden. Med andre ord flyder scenariet sammen med sansningerne i et transcendent moment. I mødet med det atmosfæriske, i den orgiastiske forening, gennemstrømmes jeg' et af sanseindtryk - et væld af syn, lugte, lyde. Uden at reducere mangfoldigheden, synes en rytmisk faktor at generere disse stimuli. Strofen (som citeres på s. 19) folder sig ud fra linien "The smoke of my own breath", hvor åndens møde med luften synliggøres.

Synlig ånde forvandles til lyden af ord, der hvirvler i vinden. Herimellem støder man på en interaktion mellem åndedræt og hjerteslag, der beskrives med nærmest fysiologiske termer. Vist står der ikke, at åndedrætsmusklernes sammentrækninger driver en luftpumpe, som sørger for luftskiftet i lungerne, ej heller, at højre hjertekammers sammentrækninger driver en blod- 
pumpe, som sørger for gennemblødningen af lungerne. Men "My respiration and inspiration....the beating of my heart..../ the passing of blood and air through my lungs," tematiserer tydeligvis kredsløbet, den gensidige afhængighed mellem hjertets pumpen og vejrtrækningen. Disse basale livstegn er som bekendt cykliske og rytmiske fænomener i menneskets fysiologi. Snarere end at anvende hjerteslag og åndedræt i overført forstand, griber Whitman direkte til pulsen. Samtidig antager „My respiration and inspiration....the beating of my heart" i al sin enkelhed en noget nær meta-rytmisk karakter. Ved at sidestille respiration, der betyder vejrtrækning, med inspiration, der både kan betyde indåndning og stimulering til kunstnerisk skabelse, kæder Whitman det fysiologiske og lyriske uløseligt sammen. Vel at mærke skrives der ikke abstrakt om hjertet og åndedrættet; fænomenerne aktualiseres som konkrete funktioner i jeg'ets krop; „my heart", "my lungs". Man kan sige, at den digteriske inspiration realiseres som sansningen af dét indre kredsløb, der forbinder jeg'et med atmosfæren.

Tidligere i indeværende afsnit påstod jeg, at en rytmisk faktor uden at reducere mangfoldigheden genererer de øvrige sanseindtryk. Strofens eksplicitte inddragelse af åndedræt og vejtrækning er selvfølgelig ikke ensbetydende med denne rytmiske faktor, omend de i særdeleshed henleder opmærksomheden på rytme og cyklus. Betragtet som verseenhed, indgår for eksempel "the beating of my heart" på lige fod med de andre entiteter $i$ strofens parataktiske opremsning. Det vil sige; det er ikke versefødder, ikke metriske mønstre, der gør disse liniers rytme medrivende. Det er derimod de karakteristiske parallelismer, der virker som „Echóes, ripples”, som ekkoer og bølgebevægelser.

Hvis man med dette in mente lægger øret til strofen, kan man høre, at første vers giver genklang såvel i liniernes som strofens struktur. Førend strofen citeres, skal det påpeges, at „,Song of Myself" stort set ikke indeholder enderim i traditionel forstand. Et sted tages der endog eksplicit afstand fra rim til fordel for en lullende nynnen: „Not words, not music or rhyme I want....not custom or lecture,/ not even the best,/ Only the lull I like, the hum of your valved voice." Dog kan de mange forskellige gentagel- 
ses-typer siges at have en rimende effekt. I stedet for homofoni mellem stavelser, korresponderer et dominerende lydmønster med et distinkt tankespil. I denne strofe er der eksempler på grammatisk-syntaktiske gentagelser; den gennemgående genetiv-form (the $x$ of), som især giver genlyd i versenes anslag, men som i det hele taget er grundlæggende for strofens tankegang. Endvidere er der eksempler på identiske repetitioner, såsom "green leaves and dry leaves" og "A few light kisses.... a few embraces", samt redundans i ordgrupper, f.eks. "loveroot, silkthread,/ crotch and vine", der alle er substantiver i ubestemt form. Ikke mindst det parataktiske og paralleliseringerne har udover en rimende effekt også en rytmisk virkning.

The smoke of my own breath,

Echoes, ripples, and buzzed whispers....loveroot, silkthread, crotch and vine,

My respiration and inspiration....the beating of my heart....

the passing of blood and air through my lungs,

The sniff of green leaves and dry leaves, and of the shore and darkcolored sea-rocks, and of hay in the barn,

The sound of the belched words of my voice.....words loosed to the eddies of the wind,

A few light kisses..... few embraces.... a reaching around of arms,

The play of shine and shade on the trees as the supple boughs wag,

The delight alone or in the rush of the streets, or along the fields and hillsides,

The feeling of health....the full-noon trill....the song of me rising from bed and meeting the sun.

Strofen udgøres af én lang sætning, der udspiles i en opremsning uden syntaktisk spænding, eller rettere uden andet end kulmination. Hermed menes, at listen ikke er progressivt orienteret mod en opløsning af spændning. Der er altså ikke tale om en udhaling af punktummet gennem digressioner, tværtom flyder sætningen fra digression til digression i associerende bølger. Udeladelsen af styrende syntaktiske principper influerer i særdeleshed på intonationen; ensartetheden bevirker en ligebyrdighed mellem enhederne, hvoraf ingen kan siges at være mere eller mindre meningsbærende end andre. Der er altså hverken et grammatisk 
eller et metrisk indeks for stemmeføringen. Disjecta membra? Jo, men samtidig er den rytmiske faktor gennemtrængende. Dels frisættes sprogets naturlige betoninger, dels indsættes de i en indre sammenhæng af gentagelser. Ovenfor har jeg udhævet strofens mest genkommende gentagelses-anslag, hvilket ikke indfanger samspillet mellem vers og strofe præcist, men i det mindste tegner kæden af ekkoer. Og det er formentlig gennem den intense samklang og genklang, gennem den tætte glidning mellem genkendelighed og udskiftelighed, repetition og variation, at strofen struktureres. Tankens flow og rytmens "ripples" stemmer overens, flydende, bølgende, bevirkende en nærmest hypnotisk harmoni, der rækker ud over såvel lyriske konventioner som prosa. Rytmikken kan til en vis grad sammenlignes med en metonymisk forskydning, idet den synes at være baseret på nærhed snarere end lighed. Forskydningen tager afsæt i en enhed, hvis potentiale så at sige udmattes. Men det er nok mere rammende at anvende den føromtalte "uniform hieroglyphic" som emblem for den rytmiske faktor, der formår at lade ensartethed og mangfoldighed spille sammen.

Strofen oprinder i og med åndedrættet som vision, "The smoke of my own breath", og udrinder i sang og solopgang: "the song of me/ rising from bed and meeting the sun." Vist er jeg'et lydhør, som Cowley påpeger. Men respirationens sammenfald med inspirationen turde give belæg for, at det orale også indspiller i den originale version af "Song of Myself". Den ensartetede hieroglyf $\mathrm{f}^{10}$ vibrerer netop mellem det auditive' og orale, som en transformation af støj til røst gennem gentagelsens første princip: rytme.

\section{"beating" - død og metrum eller liv og rytme?}

Analyserne indkredser et spektrum af forskelle mellem Dickinsons og Whitmans lyrik. De tre digte af Dickinson er udformet $\mathrm{i}$ kvartetter i common meter, og den traditionelle form får modstand af tankestregerne samt de ustabile rim. "Song of Myself" består af 52 dele, der udgøres af et varierende antal strofer eller passager, hvis linieantal ligeledes er forskellige. Hvor Dickinsons 
rimmodus problematiserer verseenhedens integritet indefra, adskiller Whitmans rimmodus sig i udgangspunktet fra det konventionelle forhold mellem vers og strofe.

Zoomer man ind på to isolerede vers, ét af hver digter, er også den metriske konstast tydelig:

Kept beating - beating - till I thought

My respiration and inspiration....the beating of my heart....

Dickinsons vers på én gang aktualiserer og forrykker den jambiske alternation. Stavelsernes skiftende betoning er regelmæssig, men regelmæssigheden stemmer ikke overens med tankestregernes friktion:

Kept beating - beating - till I thought

$\mathrm{u}-\mathrm{u} / \mathrm{-u} / \mathrm{-u}-$

Ved således at indskyde fremmedelementer i den ellers så genkendelige gangart, undergraver Dickinson enkelt og subtilt det metriske mønsters stabilitet. Den egenartede anvendelse af tankestregen bevirker, at den hver gang vækker uro i metret, blandt andet fordi pausens varighed aldrig er givet på forhånd. Dog giver det generelt mening at skandere Dickinsons digte, for om ikke andet kan det metriske mønster benyttes i en negativ indkredsning af de rytmiske friktioner. Heroverfor yder Whitmans vers i reglen skandering så stor modstand, at den klassiske notation er aldeles utilfredstillende. Skanderingen besværliggøres eller overflødiggøres - sandsynligvis deraf, at det i Whitmans free verse simpelthen ikke er versefoden, der er den dominerende enhed. De føromtalte parallelismer, som baserer rytmen, opstår snarere i et samspil mellem verselinie og strofe. Linien her indspiller i gentagelsen af genetiv-formen (the $x$ of), som jo ikke er hørbar i det isolerede vers. Alligevel afspejler linien det parataktiske og parallelistiske. Opremsning, sidestilling og gentagelse forefindes i enkeltlinien, der indeholder strofens mest gennemtrængende rytmiske figurer på et lokalt niveau. 
At Dickinson i forhold til Whitman benytter sig af mere konventionelle vers på overfladen, er ikke nødvendigvis ensbetydende med, at hendes primære enhed er versefoden. Tankestregerne bryder ofte linierne op i rytmiske enheder, der er forskudte i forhold til versefødderne, og formodentlig er disse fragmenter vitale for Dickinsons vers.

Zoomer man endnu tættere ind, denne gang på to brudstykker af versene, træder et sammenfald frem: „beating - beating -" og " ....the beating of my heart....". Begge digtere tager ordet „beating" i anvendelse. Som det er fremgået af analyserne, er der i særdeleshed forskel på, hvordan ordet sættes i spil hos henholdsvis Dickinson og Whitman. I "I felt a Funeral, in my Brain," forbindes slagene med en ceremoniel tromme, der udover at være tilknyttet død og begravelse også markerer det monotone metrum: „béating - béating -". Hvor slagene således er instrumentelle og forskelsløse hos Dickinson, er ",beating" hos Whitman en naturlig del af en organisk helhed. Tematisk hænger hjertets slag og åndedrættet utvivlsomt sammen med liv hos Whitman, og rytmisk emfaserer „....the beating of my heart...." den strømmende, bølgende rytme.

At Whitman forbinder "beating" med liv og rytme, mens Dickinson forbinder „,beating" med død og metrum, er uhyre bemærkelsesværdigt $\mathrm{i}$ et teoretisk perspektiv. Dette modsigende sammenfald synes nemlig at illustrere en problematik, der så at sige er iboende sondringen mellem metrum og rytme.

De to begreber har forskellige oprindelser, idet rytme kommer af græsk 'rheo', der betyder strøm eller bølgeagtig bevægelse, mens metrum kommer af græsk 'metron', der betyder mål. For grækerne var rytme fluktuation, altså ingenlunde kaotisk støj, men orden i bevægelse. Dette kan anskueliggøres derved, at rytme blev sammenlignet med bølgegang - ikke havets brusen, men bølgernes kommen og gåen, bølgernes gentagende og varierende bevægelser. Senere, med romerne, blev rytme imidlertid forbundet med det aritmetiske, til trods for at den fluktuerende orden i græsk forstand ikke var baseret på det numerale. Hermed blev strøm og mål nærmest uadskillelige. Med fokus på Whit- 
mans og Dickinsons modsatrettede "beating" kunne man spørge: er slag udslag af metrum eller rytme?

Hvor rytme er et fænomen, der ikke blot manifesterer sig i lyrik, men også i alskens naturlige processer, såsom årstidernes cyklus og menneskelig fysiologi, er metrik udelukkende en æstetisk forekomst. Såvel kvantitativ som kvalitativ metrik indebærer en udvælgelse af en binær opposition i sproget, henholdsvis kort-lang og tryksvag-trykstærk. Man kan definere denne reduktion som en æstetisk konvention, en rent formel størrelse. Men det er et uafklaret spørgsmål, hvorvidt denne formelle konvention hidrører fra menneskets naturlige perception. Det vides, at vi er tilbøjelige til at opfatte ensartede slag som parvise konstraster. Selv om et urs tik tik tik tik har samme styrke og samme afstand i mellem sig, hører vi uvilkårligt TIKtik TIKtik. Og vi hører vores hjerter banke DUNKdunk DUNKdunk. At hjertet slår, og dén måde, hvorpå vi hører det slå, er jo ikke et metrisk eller æstetisk, men derimod et fysiologisk og perceptionelt rytmisk fænomen. ${ }^{11}$

Disse skæringspunkter mellem metrum og rytme opererer så at sige på et andet niveau end det forhold, at Dickinsons „beating" forefindes i et digt i common meter, mens Whitmans "beating" figurerer $i$ et digt $i$ free verse. Hos Dickinson kan slagene høres som figur for det alternerende metrums indifferente, rigide trommen. Hos Whitman kan slagene høres som figur for den parallelistiske rytmes strømmen. Men ,....the béating of the héart...." kan mærkværdigt nok skanderes alternerende. Og i "beating - beating -" rokker tankestregerne ved dét metrum, slagene betoner. Kort sagt aktualiserer såvel Whitmans som Dickinsons „beating" et væsentligt spørgsmål i relationen mellem rheo og metron.

\section{Common meter}

Dickinsons „I felt a Funeral, in my Brain,", „I heard a Fly Buzz when I died-" og "I felt a Cleaving in my Mind-" eksemplificerer på dén ene side en processuel variation og på den anden side en traditionel form. En betragtelig del af Dickinsons digte er skrevet 
i samme forholdsvis enkle form som disse tre digte, altså kvartetter i common meter. Spørgsmålet om, hvad der ligger til baggrund for denne formmæssige monotoni, deler Dickinson-forskningen $i$ to lejre.

Det vides, at Dickinson-familien ejede adskillige af Rev. Isaac Watts hymnebøger. Disse protestantiske, engelske hymner består netop af kvartetter i common meter. Nogle forskere mener, at Dickinson transponerer og transformerer Watts hymnologi, idet hun distancerer sig fra såvel det konventionelle metrum som det religiøse budskab gennem formmæssige forrykkelser, bl.a. tankestregen, samt en noget nær tematisk omvending. Andre er af dén holdning, at afstanden mellem Dickinson og Watts er så stor, at Dickinson end ikke står i ambivalent gæld til hymnerne. Konflikten drejer sig ikke mindst om, hvorvidt Dickinson er fanget af hymneformen eller ej. Ordet "escape" anvendes således både af fortalere for og modstandere af, at hymnen er Dickinsons primære formelle forlæg:

Those hymns imposed themselves on - and as - Dickinson's metrical consciousness, in such a way that she could hardly escape them when she would herself write poetry. 12

Her meter was based on the simple rhythms of the hymnbook; it involved no artistic problem per se, except for the risk of monotony, which she did not always escape. 13

Far from being constrained by her form or immured within the tradition of the hymn, she escaped that tradition completely, to the point where most of her poems no longer bear even a parodic or contrasting relationship to hymns. ${ }^{14}$

De to første udsagn må gå ud fra dén antagelse, at formen snarere valgte Dickinson end omvendt; at hjemmets hymner slog sig fast $i$ hendes underbevidsthed, længe for hun begyndte at digte. Statistisk set er common meter ganske vist det hyppigste metrum hos Dickinson, men det er ikke det eneste. Endvidere findes der enkelte digte i fri form hos Dickinson - jeg skal senere fremdrage 
et eksempel - og man kunne spørge til de to første udsagn, om sådanne undtagelser blot bekræfter reglen?

Hvis man nu tyr til det tredie udsagn, hvor "Dickinson escaped that tradition completely", melder der sig imidlertid et andet spørgsmål. Nemlig; hvorfor prøvede hun så aldrig kræfter med andre og mere komplicerede lyriske formtraditioner, såsom sonetten og oden? Når man læser gennem de 1775 digte, møder man unægteligt en monotoni, der blandt andet bevirkes af det karakteristiske alternerende metrum.

\section{Free verse}

Harold Bloom mener ikke, at det mest originale ved Whitman er hans free verse, ${ }^{15}$ men ifølge T.S. Eliot, der hævdede at intet vers er frit, er det rytmen, der gør Whitman unik i verdenshistorien. Men hvad mener man egentlig, når man taler om frit vers? Man kan sige, at det frie vers' primære og generelle træk er nonmetrisk strukturering, grammatiske brud eller pauseringer samt ustabile eller manglende enderim. En sådan bestemmelse tager dog ikke højde for lingvistiske vilkår og historiske faktorer. Kort fortalt er der tre forgreninger indenfor frit vers, nemlig det franske vers libre, det tyske Freie Rhythmen og det engelsk/amerikanske free verse. Vers libre, der fulgte i forlængelse af vers libéré, frigjorde sig radikalt fra dét syllabiske kvantitetsprincip, der. regulerede fransk metrik. Med foregangsmænd som Mallarmé og Rimbaud, blev det syllabiske system undergravet. Stavelsesantallet i verselinierne blev enten gjort irrelevant, ubestemmeligt eller begge dele, blandt andet gennem en problematisering af stumme vokalers værdi som stavelser. Den franske frigørelse af verset er nærmest kanonisereret i versehistorisk henseende, og vers libre's indflydelse på det vestlige vers bør da heller ikke undervurderes. Dog må det ihukommes, for det første at den romanske metrik er syllabisk, mens den germanske metrik er syllabisk-prosodisk. Tyske og engelske frigørelser af verset må derfor indebære selvstændige refleksioner over betoningsmæssige begrænsninger. For det andet blev Freie Rhythmen introduceret i 1750'erne af Klopstock som et opgør 
med de dogmatiske restriktioner, som Martin Opitz påtvang det tyske vers i 1600-tallet. Hvor vers libre tog afstand fra den stringente kvantitative metrik, gjorde Klopstock op med Opitz indskærpelse af alternation, altså en bunden kvalitativ metrik. For begge disse frie vers gør det sig gældende, at metriske regelsæt danner afsæt for en frigørelse. I free verse, som tog form i og med Whitmans Leaves of Grass, 1855, synes det engelske sprogs metriske traditioner snarere at være forladt på forhånd.

Whitmans free verse er frit på en måde, der fik flere af Whitmans samtidige kritikere til at opfatte digtsamlingen som et prosaværk. Og er formet på en måde, der, som Pasquale Jannacone allerede i 1897 påpegede, vidner om en bevidst prosodisk teknik. 16

Et af de nok tydeligste eksempler på den føromtalte parallelistiske struktur, er en passage, som i rytmisk henseende måske umiddelbart kan minde om prosa, men syntaksens rytmiske og rimmæssige struktur viser sig ved nærmere eftersyn - eller lydhørhed - at have lyrisk stringens. Passagen udgøres af tre sekvenser, som hver i sær sidestiller to modsatte kategorier (the body/ the soul, the pleasures of heaven/the pains of hell, the first/ the latter). Til sammen paralleliserer de tre sekvenser kæden af modsætningspar. Hver sekvens er altså tvedelt, og den syntaktiske sammenkædning kan tendentielt siges at betone den første del mere end den anden. Desuden kan hvert vers atter opdeles i en trykstærk og en tryksvag del, hvilket kan illustreres som følger:

I am the poet I of the body I I

and I am the poet I of the soul.

Samtidig med denne bølgebevægelse, der i særdeleshed rækker ud over konventionel alternation, må det bemærkes, at de i alt 6 dele parvist består af ligebyrdige, korresponderende grammatiske enheder, der er fremsat i identisk rækkefølge. Altså:

\footnotetext{
123

I am $i$ the poet I of the body $\mid$ |
} 
123

and I am I the poet I of the soul. I I

$\begin{array}{lllll}1 & 2 & 3 & 1 & 2\end{array}$

The plasures I of heaven I are with me I | and the pains | of hell | 3

are with me, II

$12 \quad 3 \quad 3 \quad 1$

The first I I graft and increase | upon myself .... | | the latter |

2

3

I translate I into a new tongue. I I

Dén parallelistiske teknik kan kaldes relativt fri, for så vidt som der er tale om strukturelle mønstre. Imidlertid er den indre sammenhæng i Whitmans vers overhovedet ikke metrisk baseret, hvilket gør Whitmans vers frit på et andet grundlag end såvel det engelske som det franske. Snarere end metriske mønstre, hvori stavelsen er mindsteenhed i versefoden, er der tale om rytmiske strukturer, hvor ordet er mindsteenhed i den syntaktiske del.

Man kan delkonkluderende sige, at Dickinson filtrerer sin personlige rytme gennem common meter, idet hun spiller egenart og konvention ud mod hverandre, hvorimod Whitman udelukkende realiserer sin personlige rytme, free verse, uden inddragelse af eller henvisning til traditionelle versemål.

\section{Whitmans "barbaric yawp" \& Dickinsons „Blue Monotony"}

At Dickinson således på én gang tager afstand fra og trækker energi fra metriske konventioner, mens Whitman er løsrevet fra sådanne, kunne anspore til den slutning, at Whitman i et rytmisk perspektiv er mere moderne end Dickinson. En slutning, som imidlertid kan diskuteres.

Hos Whitman lyder det: „I sound my barbaric yawp over the roofs of the world". Dette barbariske brøl kan høres som en manifestation af en rå, vild lydlighed. Ikke for ingenting er Whitmans lyrik blevet kaldt "the poetry of barbarism". Det barbariske står i modsætning til det civiliserede, det barbariske har med det primitive at skaffe. I denne sammenhæng er det interessant, at 
Whitmans digtning har flere karakteristika til fælles med primitiv lyrik. Ikke mindst parallelismerne, der findes i al primitiv lyrik, og som spiller en grundlæggende rolle hos Whitman. Kort sagt gør det sig generelt gældende for primitiv lyrik, at synonyme og antitetiske parallelismer sammenkæder eller modstiller serier af tanker. Det er sammenkædningen eller modstillingen, der generer rytmen. Det primære rytmiske element er ikke stavelsen, men derimod ordet. Endvidere er der overenstemmelse, eller manglende sondring, mellem det fonetiske og tankemæssige niveau. Med sine barbariske brøl, der lader hånt om den vestlige metriks restriktioner, griber Whitman besynderligt nok tilbage til teknikker, der går forud for den europæiske traditionsrigdom. Hvad enten det atavistiske præg er bevidst fra Whitmans side eller ej, rejser det spørgsmålet om, hvorvidt det whitmanske free verse er en tilbagegangsproces snarere end et fremskridt.

For så vidt som Whitmans free verse har karakter àf involution, kunne man hævde, at Dickinsons særegne friktion er mere moderne. Som tidligere nævnt, findes der blandt de 1775 digte eksempler på, at Dickinson ikke var komplet bundet af hymnen. Ét af disse eksempler er digt nr. 854:

Banish Air from Air -

Divide Light if you dare -

They'll meet

While Cubes in a Drop

Or Pellets of Shape

Fit

Films cannot annul

Odors return whole

Force Flame

And with a Blonde push

Over your impotence

Flits Steam.

Dette blændende digt adskiller sig i særdeleshed fra de karakteristiske nr. 280, 465 og 937, der jo er skrevet i kvartetter og common meter. Ikke blot former digtet sig frit ud fra en rimende kup- 
let (Air- dare). Det tematiserer også et formmæssigt paradoks. Ét af versene består udelukkende af ordet "Fit", som henviser til et sammenfald mellem to former, nemlig "Cubes in a Drop/ Or Pellets of Shape", hvad man kunne beskrive som en art cirklens kvadratur. Digtets mesterlige tæthed tyder ikke just på, at Dickinson var fanget af et ubevidst formvalg! Hvis man i stedet for at se Dickinsons tilbagetrukkethed som en passiv eller selvudslettende resignation - à la ,"she accepted her destiny as an artist who in her lifetime would remain unknown"17- tager hendes 'skæbne' alvorligt som et valg, virker det også nærliggende at anskue anvendelsen af den konventionelle form som et valg. At Dickinson sjældent skrev digte i fri form og ikke udtrykte sig i f.eks. sonetform kan med andre ord udlægges som en kunstnerisk nødvendighed, en poetik, om man vil.

I det ovenfor citerede digt figurerer „a Blonde push". Ordet "push" kan betyde skub, puf, stød, tryk, energi. Et andet digt (nr. 928) involverer en blå monotoni i sin første strofe og et øjebliks energi i sin sidste strofe. „Blue Monotony“ og "An instant's Push" igangsætter og opløser således digtet. Den blå monotoni optræder i forbindelse med en sammenligning af hjerte og hav, der er aldeles frapperende i metrisk og rytmisk henseende.

The Heart has narrow Banks

It measures like the Sea

In mighty - unremitting Bass

And Blue Monotony

Som jeg tidligere har været inde på, er rytme i begrebets oprindelse knyttet til strømmende bevægelse og bølgegang. Derudover er hjertets slag et eksempel på rytme som fysiologisk fænomen. Ligesom hos Whitman, virker hjertet i dette digt snarere fysisk end symbolsk. Verbet "measures" $i$ anden linie må med rimelighed siges at kunne henvise til metrik og rytme, eftersom "measure" som substantiv betyder versemål på engelsk. Følgelig figurerer hjertet hos Dickinson i en forholdsvis eksplicit forbindelse med en metrisk-rytmisk problematik. Den konstante basgang og blå monotoni, som omtales i første strofe, kan tilsynela- 
dende læses som figurer for den metriske metronom, den ensformige alternation.

Men. Hjertet har smalle bredder, det måler ligesom havet, hedder det. Imidlertid har et hav jo ikke smalle bredder, tværtimod. Hvad digtet antageligt implicerer med sidestillingen af den lille biologiske puls og den store oceaniske bølgegang er dels en omvending af størrelsesforhold. Dels en art fusion af mål og strøm, det numerale og flukturale.

I det metrisk-rytmiske perspektiv kan digtet, som dog ingenlunde er entydigt, læses som en stillen spørgsmål ved såvel forskel som lighed mellem metrum og rytme. Er hjertets slag, som havets bølgen, en ur-rytme, der kæder mennesker sammen med en strøm af tid? Eller tæller hjertets pumpen hvert øjeblik, man kommer ét slag tættere på det sidste, på døden? Er metrets alternation afledt af hjertets rytme, altså; mimer den fonetiske tvedeling i trykstærke og tryksvage betoninger hjertets slag? Eller står metret i modsætning til blodets strømmen gennem digtet, som en barriere? Dette nærmest ontologiske problemkompleks synes Dickinson at udforske med afsæt i en "Blue Monotony". Som det fremgik af citaterne fra Dickinson-forskningen, er hun blevet kritiseret for ikke altid at undslippe den såkaldte risiko for monotoni, som det hymniske forlæg indebærer. Den blå monotoni synes imidlertid at indgå $i$ et raffineret og gennemreflekteret formspil, en lyrisk quest vedrørende zonen mellem metrum og rytme. I denne quest synes ordet „Push" at indgå. I digt nr. 928, der er et eksempel på Dickinsons karakteristiske konventionelle form, fører et øjebliks stød eller energi til opløsning. I digt nr. 854, der er skrevet i fri form, fører "a Blonde push" til en overvindelse af impotens. Andetsteds optræder denne energi, der er erotisk ladet, i direkte forbindelse med fryd: "the push of Joy" (f.eks. i digt $n r, 251$ og 276).

Delkonklusionen lød, at Dickinson filtrerer sin egen personlige rytme gennem common meter, idet hun spiller egenart og konvention ud mod hverandre, hvorimod Whitman udelukkende realiserer sin personlige rytme, free verse, uden inddragelse af eller henvisning til traditionelle versemål. Konkluderende må dén modifikation tilføjes, at Whitmans banebrydende 
free verse er iboende en gestus til primitive rytmeformer. Endvidere må det udledes, at Dickinson ikke er fanget af den specifikke hymneform; dertil er hendes lyriske quest for vidtrækkende, ja, universel. Hos Dickinson lades monotoni og energi henholdsvis positivt og negativt, men indgår samtidig i et samspil. Monotoni kan siges at være en formalitet, der er et vilkår for frisættelsen af Dickinsons friktion og drivkraft. Gentagelsen, der ligger i det parallelistiske, kan siges at være uundværlig for Whitmans mangfoldighed. "If you would understand me go to the heights or the watershore", hedder det hos Whitman, og videre: "The nearest gnat is an explanation and a drop or the motion of waves a key," Bølgernes bevægelse er én nøgle, men ingenlunde noglen til Whitmans lyrik. Som rytmisk figur er bølgerne netop uløseligt forbundet med udskiftelighed og dermed også mangfoldighed.

Spørgsmålet om, hvem af de to digtere, der er mest moderne, er - i en rytmisk optik - i grunden uinteressant at besvare. For det første sætter de begge lyrisk rytme i værk på en særegen og nyskabende måde. For det andet, og det kan ikke understreges nok, bevæger deres stemmer sig på to forskellige frekvenser; deres røster kan ikke transponeres til samme toneart.

På den ene side er monotoni og pluralitet to sidestillede, men uforenelige linier i dén diversitet, som præger amerikansk lyrik. På den anden side synes sporene at krydse hinanden dér, hvor Whitmans parallelismer får monoton redundans, og hvor Dickinsons energi tangerer det mangfoldige.

\section{Noter}

1. "I'm Nobody", lyder det i digt nr. 288 i Emily Dickinson The Complete Poems redigeret og med forord af Thomas J. Johnson, Fabers \& Fabers, 1975. „I celebrate myself”, lyder det på s. 25 i Walt Whitman Leaves of Grass. The First (1855) Edition, redigeret og med forord af Malcolm Cowley, Penguin Classics, 1986.

2. "No Western poet, in the past century and a half, overshadows Walt Whitman and Emily Dickinson", står der på s. $247 \mathrm{i}$ Harold Blooms The Western Canon, New York 1994. 
3. Se Dickinson Selected Letters, redigeret af Thomas H. Johnson, The Belknap Press of Harvard University Press, 1986, brev nr. 265, s. 174.

4. Jfr. Britta Lindberg-Seyersted Emily Dickinson's Punctuation. Oslo, 1976, p.13.

5. Desuden er dét karakteristikum, at bestemte ord er stavet med stort, udeladt i denne version.

6. Jfr. Britta Lindberg-Seyersted Emily Dickinson's Punctuation s. 14. Her kan det håndskrevnemanuskripț også tages i øjesyn.

7. Agniezska Salska. Walt Whitman and Emily Dickinson. Poetry of the Central Consciousness. Philadelphia, 1985, s.128, min oversættélse.

8. Fra digt nr. 501.

9. Her benyttes Walt Whitman Leaves of Grass. A Northon Critical Edition, redigeret af Scully Bradley og Harold W. Blodgett, New York, 1973. 10. Det understreges, at den ensartede hieroglyf, oversat efter Whitmans "uniform hieroglyphic", opfattes som et skriftligt emblem for den rytmiske faktor, idet emblemet ikke i sig selv er den rytmiske faktor, men snarere dennes mærkat.

11, Se f.eks. Jørgen Fafner Digt \& Form. Klassisk og moderne verslære, C.A. Reitzel 1989, §55 om rytmekarakter, s. 85, hvor Fafner skriver om, hvorledes vi ","gestalter" slagrækken i enten betonede eller ubetonede elementer".

12. James Olney: The language(s) of poetry: Walt Whitman Emely Dickinson, Gerald Manley Hopkins. Athens and London, 1993, s. 27, min kursivering. (Det bør tilføjes, at Olney citerer en hymne af Watts).

13. Lindberg-Seyersted Emily Dickinson's Punctuation, s. 32, min kursivering af "escape".

14. Timothy Morris "The Development in Dickinson's Style", in: American Literature, nr. 60, 1988, s. 27, min kursivering.

15. Se s. 248 i Harold Bloom The Western Canon, New York 1994.

16. Nedenstående eksempel bygger direkte på Jannacone's analyse af samme citat, dog fra "Deathbed" udgaven, p. 92-94. Pasquale Jannacone Walt Whitman's Poetry and the Evolution of Rhytmic Forms, der altså første gang udkom i 1897, men som er genudgivet $i$ 1973, er i alle måder et pionerarbejde inden for spørgsmålet om Walt Whitmans free verse, og bogen er stadig et ensomt, men særdeles aktuelt hovedværk i dette felt. 17. Citatet er fra T. H. Johnsons „Introduction”, p. vii, i Dickinsons The Compléte Poems 